\title{
Eksplorasi Pola Interaksi dan Penggerak Opini dalam Jaringan Sosial pada Percakapan Bom Surabaya 2018 di Media Sosial Twitter
}

\author{
Deacta Ayu Digpasari ${ }^{1}$, Risca Septi Widyawati ${ }^{2}$, Andry Alamsyah ${ }^{3}$ \\ 1,2,3 Program Studi S1 Manajemen Bisnis Telekomunikasi dan Informatika, Universitas Telkom \\ 1 deactaayud@student.telkomuniveristy.ac.id \\ ${ }^{2}$ riscaaaw@student.telkomuniveristy.ac.id \\ 3andrya@telkomuniversity.ac.id
}

\begin{abstract}
Abstrak - Penggunaan dari media sosial kini semakin marak digunakan oleh masyarakat umum karena media sosial membantu menghubungkan satu sama lain tanpa mengenal waktu dan jarak serta memberikan sarana untuk penggunanya dapat berinteraksi. Salah satu media sosial terpopuler adalah Twitter. Melalui Twitter dapat dilakukan analisis konteks sosial menggunakan sistem komputasi atau biasa disebut dengan Social Computing. Salah satu metode yang dapat dilakukan adalah Social Network Analysis (SNA) yang dapat mengidentifikasi pola interaksi sosial yang terjadi antar pengguna dalam suatu jaringan. Penelitian ini berjudul "Eksplorasi Pola Interaksi \& Penggerak Opini dalam Jaringan Sosial pada Percakapan Bom Surabaya 2018 di Media Sosial Twitter" memiliki tujuan untuk mengidentifikasi aktor yang paling berpengaruh pada interaksi percakapan mengenai bom di Surabaya pada tahun 2018 yang dapat diprediksi sebagai penggerak opini dalam diseminasi informasi pada jaringan tersebut. Penelitian ini dilakukan dengan mengumpulkan semua tweet (reply, mention, dan retweet) yang berisi percakapan menggunakan bahasa Indonesia mengenai peristiwa bom di Surabaya pada tahun 2018 pada rentang waktu 13-21 Mei 2018 tanpa batasan lokasi. Jenis penelitian ini merupakan penelitian deskriptif dengan menggunakan metode SNA. Ukuran yang diteliti adalah degree centrality, closeness centrality, betweeness centrality, dan eigenvector centrality. Dari hasil penelitian didapatkan 3081 nodes (akun) dan 4163 edges (interaksi) yang terjadi selama tujuh hari pada interaksi sosial percakapan mengenai bom di Surabaya tahun 2018. Berdasarkan penelitian tersebut dapat diindentifikasi bahwa aktor yang paling berpengaruh dalam jaringan sosial tersebut adalah akun Jokowi.
\end{abstract}

Kata Kunci- Big Data, Analisis Jejaring Sosial, Penggerak Opini, Pola Interaksi, Media Sosial

\section{PENDAHULUAN}

\section{A. Latar Belakang}

Pada era modern ini, internet merupakan hal yang sering digunakan oleh banyak orang untuk mendapatkan informasi, membangun komunikasi dan menjangkau dunia yang lebih luas. Pengguna internet di Indonesia mengalami pertumbuhan sebesar $51 \%$ dalam kurun waktu satu tahun, sehingga Indonesia menjadi negara yang memiliki pertumbuhan pengguna internet tertinggi di dunia. Hal tersebut jauh melebihi pertumbuhan rata-rata global yang hanya sebesar $10 \%$ [1]. Perkembangan penggunaan internet tersebut juga diiringi dengan perubahan aktivitas manusia dalam penggunaan gadget memunculkan adanya cloud computing sehingga melahirkan sebuah fenomena baru yang dikenal dengan Big Data. Dengan adanya fenomena tersebut memberikan kemudahan untuk memperoleh data dari berbagai sumber seperti halnya melalui media sosial yang merupakan sumber data terbesar dimana selalu mengalami perkembangan yang menjadi faktor membludaknya sebuah data. Salah satu media sosial terpopuler beberapa tahun terakhir adalah jejaring sosial mikroblog, Twitter. Twitter banyak digunakan oleh masyarakat karena sifatnya open platform yang mengizinkan pihak ketika untuk dapaat memanfaatkan fasilitas pada Twitter.

Peristiwa Bom Surabaya 2018 merupakan rangkaian kejadian meledaknya bom di beberapa titik daerah Surabaya. Beberapa merupakan tempat ibadah yaitu Gereja Santa Maria Tak Bercela, GKI Diponegoro, Gereja Pantekosta Pusat Surabaya (GPPS) dan tempat lainnya adalah Markas Polrestabes Surabaya. Peristiwa tersebut terjadi pada Minggu, 13 Mei 2018 dan Senin, 14 Mei 2018. Peristiwa peledakan bom telah banyak memakan korban meninggal dan luka itu dilakukan oleh satu keluarga dengan motif untuk melakukan pengeboman bunuh diri. Peristiwa ini membuat ramai dibincangkan oleh masyarakat di media sosial khususnya Twitter sebagai bentuk belasungkawa dan kepedulian. Hal tersebut membuat peristiwa peledakan bom di Surabaya menjadi Indonesian trending topic pada Twitter. Dengan mengetahui pola interaksi percakapan bom Surabaya menggunakan metode Social Network Analysis akan terlihat aktor - aktor yang terlibat dan aktor yang berperan penting dalam jaringan sehingga dapat memprediksi aktor yang dapat menggerakkan dan menggiring opini publik terhadap peristiwa bom di Surabaya tahun 2018.

Dengan latar belakang yang terpapar diatas, Penulis mengangkat penelitian yang berjudul "Eksplorasi Pola Interaksi \& Penggerak Opini Dalam Jaringan Sosial Pada Percakapan Bom Surabaya 2018 Di Media Sosial Twitter"

\section{B. Perumusan Masalah}

Berdasarkan latar belakang yang telah diuraikan di atas, maka rumusan masalah dalam penelitian ini adalah: 
1) Bagaimana pola interaksi sosial percakapan mengenai peristiwa Bom Surabaya 2018 di media sosial Twitter?

2) Siapa penggerak opini pada pola interaksi sosial percakapan mengenai peristiwa Bom Surabaya 2018 di media sosial Twitter?

\section{Tujuan Penelitian}

Berdasarkan latar belakang dan permasalahan yang dirumuskan sebelumnya, penelitian ini bertujuan:

1) Untuk mengetahui pola interaksi sosial percakapan mengenai Peristiwa Bom Surabaya 2018 di media sosial Twitter.

2) Untuk mengetahui penggerak opini pada pola interaksi sosial percakapan mengenai Peristiwa Bom Surabaya 2018 di media sosial Twitter.

\section{TINJAUAN PUSTAKA}

\section{A. Big Data}

Big Data mengacu pada kumpulan data yang ukurannya besar sehingga dibutuhkan sebuah perangkat lunak untuk menangkap, menyimpan, mengelola, dan menganalisis [2]. Hal yang utama dalam Big Data adalah meningkatnya arus kecepatan dan bertambahnya data yang sangat eksponensial serta variasi data yang semakin banyak sehingga menciptakan sebuah tantangan baru seperti tantangan untuk memahami data agar menghasilkan sebuah informasi yang bernilai.

Berdasarkan pengertian yang ada, sebuah data dapat dikatakan Big Data apabila memenuhi tiga karakteristik yang disebut dengan "3 V". Terdapat tiga karakteristik big data diantaranya adalah [3]:

- Volume : Berkaitan dengan kuantitas atau jumlah data yang besar dimana dibutukan ruang penyimpanan yang besar dan proses analisis yang lebih detail.

- Velocity : Berkaitan dengan kecepatan arus data dan kemampuan mengumpulkan data secara real time.

- Variety : Berkaitan dengan keragaman data, bentuk atau tipe data akan semakin bervariasi bergantung dengan banyaknya sumber data.

\section{B. Media Sosial}

Pada dasarnya manusia memiliki jiwa sosial yang tidak dapat dicegah untuk dapat berhubungan dengan manusia lain. Media sosial telah memberikan manusia fasilitas sehingga mereka mudah terhubung dengan orang lain untuk memenuhi kebutuhan dan keinginan sosial mereka [4]. Media sosial juga memfasilitasi penggunanya untuk meningkatkan jumlah pertemanannya. Media sosial mengubah cara komunikasi individu, organisasi, dan masyarakat secara substansial yang membuat komunikasi menjadi lebih cepat dan lebih mudah [5].

\section{Social Network Analysis}

Social Network Analysis merupakan sebuah perspektif yang unik untuk melihat struktur yang terbentuk dalam masyarakat. Dalam bisnis, SNA dapat dimanfaatkan untuk menganalisis alur komunikasi dalam suatu organisasi atau hubungan dengan partner bisnis dan pelanggan [6]. Social network analysis dapat diaplikasikan dalam berbagai cara, baik dalam media sosial ataupun di luar media sosial [7]. Social network analysis berguna untuk memahami individu maupun kelompok. Ilmu SNA berpusat pada konsep mengenai hubungan manusia, siapa diri kita, dan bagaimana perilaku kita.

Konsep dasar Social Network Analysis adalah sebagai berikut [6]:

1. Networks, untuk merepresentasikan berbagai macam jaringan.

2. Tie Strength, untuk mengidentifikasi kuat atau lemahnya hubungan dalam suatu jaringan.

3. Key Players, untuk mengidentifikasi pemain kunci atau sentral yang ada dalam suatu jaringan.

4. Cohesion, untuk mengukur jaringan secara menyeluruh.

\section{Centrality}

Salah satu pendekatan pertama dalam menganalisis jaringan sosial adalah untuk mengukur kekuatan, pengaruh, atau karakteristik individu lain berdasarkan pola hubungan mereka [7]. Fungsi dari centrality adalah untuk mendefinisikan aktor yang paling berpengaruh dalam suatu jaringan sosial [8]. Terdapat 4 jenis model perhitungan dalam centrality yaitu: degree centrality, betweenness centrality, closeness centrality dan eigenvector centrality [9].

\section{Degree Centrality}

Jumlah hubungan atau relasi yang dimiliki oleh aktor dengan aktor lain. Aktor dengan jumlah relasi paling banyak atau memiliki degree paling tinggi akan menjadi pusat dalam suatu jaringan dan mempunyai pengaruh yang besar dalam jaringan tersebut [10].

2. Betweenness Centrality

Jumlah jalur terpendek yang melewati seorang aktor. Aktor dengan betweenness paling tinggi memiliki peran yang besar untuk menghubungkan aktor atau kelompok lain. Aktor dengan nilai betweenness tertinggi memiliki kemampuan untuk mengontrol arus informasi yang terjadi dalam jaringan yang bisa disebut dengan key player [10].

3. Closeness Centrality

Jarak aktor dengan seluruh aktor lain yang ada dalam satu jaringan dengan berfokus pada jalur terpendek dari setiap aktor ke aktor lain. Closeness dapat digunakan sebagai ukuran berapa lama waktu yang dibutuhkan agar informasi menyebar dari satu aktor ke aktor lainnya [10].

\section{Eigenvector Centrality}

Ukuran dari pengaruh yang dimiliki seorang aktor dalam jaringan. Hal tersebut merepresentasikan bahwa hubungan dengan aktor yang memiliki nilai tinggi akan memiliki pengaruh lebih besar dalam jaringan tersebut daripada dengan aktor yang memiliki nilai lebih rendah [10]. 


\section{E. Penggerak Opini}

Penggerak opini atau pemimpin opini merupakan seseorang yang mempengaruhi orang lain secara informal berdasarkan tindakan atau perilaku. Seperti teman, saudara, dan orang berpengaruh lainnya yang memiliki ikatan kuat terhadap perilaku konsumsi [11].

\section{F. Diseminasi Informasi}

Diseminasi adalah suatu media yang digunakan untuk menyampaikan atau menyebarkan dalam hal ini berupa informasi kepada publik yang bertujuan untuk mempengaruhi mereka dalam cara berpikir atau pengambilan suatu keputusan. Saat ini media sosial khususnya Twitter menjadi suatu alat diseminasi informasi sebab para penggunanya dapat membagikan apapun sehingga hal tersebut dapat mempercepat proses penyebaran informasi [12].

\section{G. Interaksi}

Sebagai makhluk sosial, suatu individu perlu untuk berinteraksi dengan individu lain karena pada dasarnya manusia tidak bisa hidup sendiri maka diperlukannya manusia lain dalam kehidupannya. Pengertian dari interaksi sendiri adalah suatu hubungan timbal balik yang dimiliki oleh individu yang melibatkan orang lain untuk melakukan aktivitas dari yang sederhana hingga kompleks [13]. Semakin dewasa suatu individu maka tingkat interaksinya semakin meluas dan berkembang. Interaksi dapat dilakukan melalui berbagai cara salah satunya melalui media sosial. Dengan adanya media sosial khususnya Twitter, interaksi antar individu semakin mudah karena dibantu dengan teknologi internet. Interaksi tersebut dapat berupa tweet, reply, dan mention.

\section{METODOLOGI}

Penelitian ini menggunakan metode kualitatif dengan maksud melihat dan menganalisis interaksi user di media sosial mengenai peristiwa Bom Surabaya 2018. Sehingga akan terlihat pola interaksi dalam percakapan tersebut. Sejalan dengan itu penelitian ini termasuk dalam penelitian deskriptif dimana dalam penelitian ini dapat menentukan dan menggambarkan aktor yang dapat menggiring opini publik di media sosial Twitter.

Dalam penelitian ini menggunakan data dari media sosial Twitter berupa tweets, reply, dan mention dengan keyword berupa hashtags \#SuroboyoGakWedi \#PrayForSurabaya \#KamiTidakTakut \#SuroboyoWani \#KamiTidakTakutTeroris \#SurabayaBerduka \#SuroboyoTidakTakut \#TerorisJANCUK \#BersamaLawanTeroris \#BomSurabaya pada rentang waktu 13 Mei 2018 hingga 21 Mei 2018 dengan menggunakan bahasa Indonesia. Pengambilan data digunakan dengan teknik data crawling dengan software Rstudio dan teknik visualisasi dengan software gephi versi 0.9.2.

\section{HASIL DAN PEMBAHASAN}

\section{A. Network Percakapan Mengenai Bom Surabaya 2018}

Berikut ini data hasil penelitian menggunakan metode Social Network Analysis dengan menggunakan software Gephi versi 0.9.2. Sumber data menggunakan Twitter berupa tweets, reply, dan mention. Penelitian dilakukan berdasarkan data dengan menggunakan hashtags yang dipilih pada media sosial Twitter dalam rentang waktu satu minggu dari 13 Mei 2018 - 21 Mei 2018. Penelitian ini menghasilkan network yang memiliki 3081 nodes dan 4163 edges dengan tipe grafik menggunakan undirected karena pada jaringan ini tidak memperhatikan arah dari interaksi yang terjadi dalam percakapan. Dapat diidentifikasi bahwa jaringan tersebut memiliki kepadatan yang tergolong rendah atau kecil karena properti pengukuran kepadatan jaringan yaitu graph density memiliki nilai 0,001 atau $0,1 \%$. Kepadatan jaringan digolongkan tinggi ketika nilai density mendekati 1 dan digolongkan rendah ketika nilainya mendekati 0 . Kepadatan jaringan tersebut renggang karena rendahnya intensitas interaksi antar aktor yang terjadi mengenai peristiwa Bom Surabaya 2018.

Pada jaringan tersebut dapat diketahui besaran diameter dengan cara mencari jalur terdekat antar node yang memiliki ikatan hubungan paling jauh. Hasil penelitian menunjukkan bahwa diameter jaringan tersebut bernilai 18. Hal tersebut dapat diartikan jarak terpendek untuk mencapai node terjauh sebesar 18 edge.

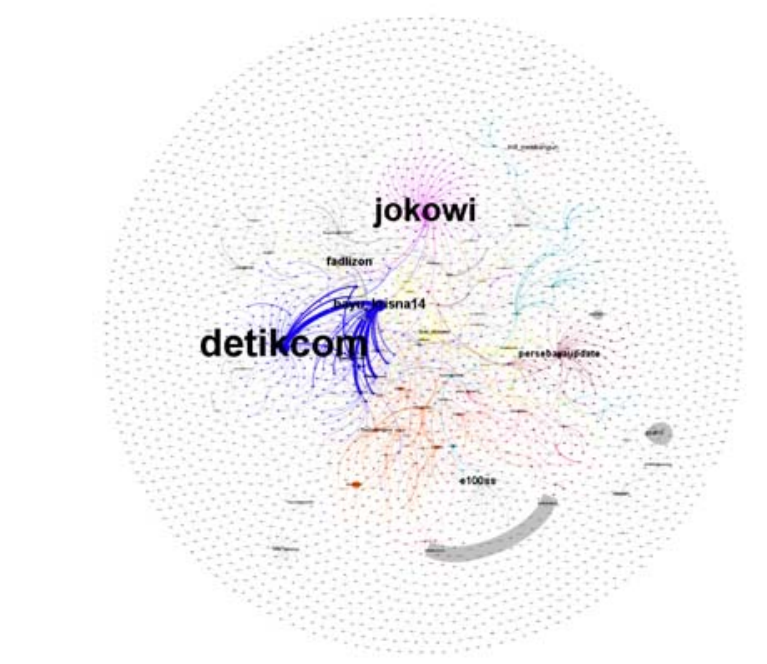

Gambar. 1 Visualisasi network percakapan peristiwa Bom Surabaya 2018

Berdasarkan jaringan sosial tersebut dapat diidentifikasi properti modularity class yang merupakan kecenderungan data untuk berkelompok dari interaksi yang terjadi. Secara keseluruhan, ditemukan bahwa terdapat 845 kelompok atau komunitas dalam jaringan sosial tersebut yang memiliki nilai modularity class sebesar 0,8 . Hal tersebut menandakan bahwa jarak pembeda antar kelompok atau komunitas tergolong cukup jauh. Nilai modularity class yang mendekati 1 menandakan jarak antar kelompok semakin jauh dan terpisah.

\section{B. Degree Centrality}


Pengukuran degree centrality dilakukan untuk mengetahui jumlah relasi yang dimiliki suatu node terhadap node lainnya pada suatu jaringan. Degree centrality bertujuan untuk mengetahui node atau aktor yang paling berperan dalam jaringan berdasarkan banyaknya relasi atau hubungan dengan aktor lain. Tabel I menjelaskan bahwa dalam jaringan sosial ini, akun Jokowi memiliki nilai degree centrality tertinggi bernilai 108 yang diartikan bahwa akun Jokowi memiliki interaksi berupa tweets, reply, dan mention paling tinggi di media sosial Twitter. Akun lainnya yang memiliki nilai degree centrality tertinggi adalah media berita (Detikcom), politikus (Fadlizon), radio (E100ss), klub sepak bola (Persebayaupdate). Hal tersebut dapat diartikan bahwa akun yang memiliki nilai degree centrality tertinggi yaitu akun Jokowi merupakan nodes yang berperan dalam diseminasi informasi mengenai percakapan peristiwa Bom Surabaya 2018 pada media sosial Twitter.

TABEL I

DAFTAR Nilai DegREe CENTRALITY TERTINGGi

\begin{tabular}{|c|l|c|}
\hline Peringkat & \multicolumn{1}{|c|}{ Nama Akun } & Nilai Degree \\
\hline $\mathbf{1 .}$ & Jokowi & 108 \\
\hline $\mathbf{2 .}$ & Detikcom & 91 \\
\hline $\mathbf{3 .}$ & Fadlizon & 55 \\
\hline $\mathbf{4 .}$ & E100ss & 53 \\
\hline $\mathbf{5 .}$ & Persebayaupdate & 53 \\
\hline
\end{tabular}

\section{Closeness Centrality}

Pengukuran closeness centrality digunakan untuk mengetahui banyaknya satu node yang dikenal oleh node lain dalam jaringan dan mengidentifikasi node yang bisa menjangkau node lainnya dengan jarak terpendek. Nilai closeness centrality yang mendekati atau sama dengan 1,0, maka semakin dekat jarak node tersebut dengan node lainnya. Tabel II menjelaskan bahwa jaringan sosial ini, terdapat 5 akun yang memiliki nilai closeness centrality sebesar 1,0 yang antara lain terdiri dari politikus muda, influencer, dan blogger yaitu akun Sahabatgusrommy, Alvinchong123, Ardi_riau, Elfizal, dan Giewahyudi. Hal tersebut dapat diartikan bahwa akun di atas memiliki kemampuan lebih cepat dan mudah ketika melakukan interaksi dengan node lainnya karena memiliki jarak yang dekat. Sehingga akun yang memiliki nilai closeness centrality tertinggi dapat digunakan sebagai media diseminasi informasi yang cepat karena dapat berkomunikasi dengan banyak node tanpa melewati banyak node lain sebagai perantara.

TABEL III

DAFTAR NiLAi CLOSENESS CENTRALITY TERTINGGI

\begin{tabular}{|c|l|c|}
\hline Peringkat & \multicolumn{1}{|c|}{ Nama Akun } & Nilai Degree \\
\hline $\mathbf{1 .}$ & Sahabatgusrommy & 1,0 \\
\hline $\mathbf{2 .}$ & Alvinchong123 & 1,0 \\
\hline $\mathbf{3 .}$ & Ardi_riau & 1,0 \\
\hline $\mathbf{4 .}$ & Efrizal & 1,0 \\
\hline $\mathbf{5 .}$ & Giewahyudi & 1,0 \\
\hline
\end{tabular}

\section{Betweenness Centrality}

Pengukuran betweenness centrality bertujuan untuk mengukur sentralitas suatu node dalam jaringan. Betweenness centrality dapat diartikan sebagai pengaruh suatu node dalam jaringan karena node tersebut berperan sebagai penghubung atau jembatan ke node lain. Keberadaan node tersebut dirasa penting karena jika node tersebut dihilangkan maka akan mengganggu kegiatan komunikasi dalam suatu jaringan sehingga informasi akan sulit untuk diteruskan. Pada table III menjelaskan bahwa pada jaringan sosial tersebut, akun Jokowi memiliki nilai closeness centrality tertinggi yaitu 277221,737 yang berarti akun Jokowi memiliki pengaruh besar dalam jaringan karena menjadi aktor penghubung atau jembatan dari seluruh arus informasi percakapan peristiwa Bom Surabaya 2018 di media sosial Twitter. Hal ini menjadikan banyak node lain yang bergantung terhadap tweets, mention, dan reply yang dilakukan oleh akun Jokowi. Dan akun lainnya yang memiliki nilai betweenness centrality tertinggi adalah media berita (Detikcom), pengguna Twitter (Duta_Hidayad), politikus (Fadlizon), dan klub sepak bola (Persebayaupdate).

TABEL IIIII

DAFTAR NILAI BETWEENNESS CENTRALITY TERTINGGI

\begin{tabular}{|c|l|c|}
\hline Peringkat & \multicolumn{1}{|c|}{ Nama Akun } & Nilai Degree \\
\hline $\mathbf{1 .}$ & Jokowi & 277221,737 \\
\hline $\mathbf{2 .}$ & Detikcom & 243626,535 \\
\hline $\mathbf{3 .}$ & Duta_Hidayad & 200086,193 \\
\hline $\mathbf{4 .}$ & Fadlizon & 130780,008 \\
\hline $\mathbf{5 .}$ & Persebayaupdate & 121099,104 \\
\hline
\end{tabular}

\section{E. Eigenvector Centrality}

Pengukuran Eigenvector Centrality digunakan untuk mengidentifikasi node yang memiliki performa paling baik dan mengukur seberapa pentingnya node tersebut dalam jaringan sosial. Pada table IV memaparkan bahwa akun Jokowi memiliki nilai Eigenvector Centrality tertinggi dalam jaringan yaitu 1.0 dan beberapa akun lainnya yang memiliki nilai tertinggi adalah media berita (Detikcom), pengguna Twitter (Duta_Hidayad dan Bayu_krisna14), dan politikus (Fadlizon). Hā tersebut mengidentifikasi bahwa akun dengan nilai eigenvector centrality tertinggi memiliki performa yang baik dalam hal interaksi atau komunikasi dengan node lain sehingga diseminasi informasi dalam jaringan tersebut dapat terjadi dengan baik.

TABEL IVV

DAFTAR NiLAi EIGENVECTOR CENTRALITY TERTINGGI

\begin{tabular}{|c|l|c|}
\hline Peringkat & \multicolumn{1}{|c|}{ Nama Akun } & Nilai Degree \\
\hline $\mathbf{1 .}$ & Jokowi & 1,0 \\
\hline $\mathbf{2 .}$ & Detikcom & 0,878 \\
\hline $\mathbf{3 .}$ & Duta_Hidayad & 0,439 \\
\hline $\mathbf{4 .}$ & Bayu_krisna14 & 0,347 \\
\hline $\mathbf{5 .}$ & Fadlizon & 0,338 \\
\hline
\end{tabular}

\section{KESIMPULAN DAN SARAN}

Berdasarkan penelitian yang telah dilakukan dapat disimpulkan bahwa jaringan sosial percakapan mengenai 
peristiwa Bom Surabaya 2018 di media sosial Twitter dengan menggunakan graph type undirected memiliki 4163 interaksi dari 3081 pengguna Twitter yang terlibat dalam percakapan topik tersebut. Jaringan sosial yang terbentuk memiliki nilai density sebesar 0,001 atau $0,1 \%$ yang mengakibatkan jaringan tersebut memiliki kepadatan yang renggang. Hal tersebut dapat terjadi karena rendahnya intensitas interaksi yang terjadi di dalam jaringan. Diameter dari jaringan sosial tersebut bernilai 18 yang menandakan jarak terpendek untuk mencapai node terjauh sebesar 18 edge atau relasi. Berdasarkan visualisasi yang terbentuk juga dapat terindentifikasi adanya kelompok atau komunitas yaitu sebesar 845 kelompok yang memiliki nilai modularity class sebesar 0,8 yang berarti jarak pembeda antar kelompok tergolong cukup jauh dan terpisah. Node atau aktor yang paling berpengaruh dalam jaringan sosial percakapan peristiwa Bom Surabaya 2018 secara keseluruhan adalah akun Jokowi. Akun Jokowi memiliki nilai degree centrality, betweenness centrality, dan eigenvector centrality tertinggi dibandingkan dengan akun lainnya dalam jaringan. Hal ini dapat diartikan bahwa akun Jokowi merupakan aktor yang paling berpengaruh dalam jaringan karena memiliki hubungan paling banyak dengan aktor lain, menjadi aktor yang menjembatani atau menghubungkan banyak node di dalam jaringan, dan memiliki performa paling baik dalam berinteraksi dan berkomunikasi dengan node lain. Sedangkan, akun Sahabatgusrommy memiliki nilai tertinggi pada closeness centrality yang menandakan bahwa akun tersebut memiliki jarak terdekat dengan node lain dalam jaringan. Sehingga, akun Jokowi merupakan akun yang berperan penting dalam jaringan yang dapat dimanfaatkan sebagai penggerak opini publik terkait dengan peristiwa Bom Surabaya 2018 yang berfungsi dalam hal diseminasi atau penyebarluasan informasi yang cepat dan mudah pada media sosial Twitter. Akun Jokowi merupakan akun yang memiliki keterikatan yang tinggi dengan node lain yang menciptakan daya tarik bagi node lain dalam jaringan sehingga opini yang dihasilkan dari akun Jokowi dapat menggiring pemikiran publik terhadap topik peristiwa Bom Surabaya 2018.

Saran terkait penelitian ini untuk peneliti selanjutnya antara lain diharapkan penelitian selanjutnya dapat menggunakan fenomena lain yang marak diperbincangkan pada media sosial Twitter, diharapkan pula penelitian selanjutnya dapat dilakukan dalam rentang waktu yang lebih lama sehingga data yang digunakan berjumlah lebih banyak maka dapat mempertajam hasil analisis penelitian, dan harapannya peneliti selanjutnya dapat memperbanyak pengukuran dan metric dari metode Social Network Analysis.

\section{UCAPAN TERIMA KASIH}

Kami mengucapkan terima kasih kepada Tuhan Yang Maha Esa, pihak - pihak yang membantu dalam proses penyelesaian penelitian ini, serta Tim JIEET yang telah memberikan kesempatan sehingga jurnal ini dapat dipublikasikan. Diharapkan jurnal penelitian ini dapat memberikan manfaat bagi pembaca dan peneliti selanjutnya.

\section{REFERENSI}

[1] We Are Social. 2017. Digital in 2017 : Global Review [online]. https://wearesocial.com/special-reports/digital-in-2017-globaloverview, tanggal akses: 1 September 2017.

[2] McKinsey Global Institute. 2011. Big data: The next frontier for innovation, competition, and productivity.

[3] Blasiak, Kevin. 2014. Big Data; A Management Revolution. Finland: Helsinki Metropolia University of Applied Sciences.

[4] Martinka, Leslie. 2012. How Social Media Communities Impact Consumer Behavior. Gonzaga University.

[5] Baruah, T. D. 2012. Effectiveness of Social Media as a tool of communication and its potential for technology enabled connections: A micro - level study. International Journal of Scientific and Research Publications. Vol.2, Iss.5.

[6] Cheliotis, Giorgos Dr. 2010. Social Network Analysis (SNA). Singapore: National University of Singapore.

[7] Tsvetovat, Maksim., Kouznetsov, Alexander. 2011. Social Network Analysis for Startups. California: O'Reilly Media, Inc.

[8] Mincer, Marcin. dan Niewiadomska-Szynkiewicz, Ewa. 2012. Application of Social Network Analysis to the Investigation of Interpersonal Connections. Journal of Telecommunications and Information Technology, 2, 83-91. Retrieved from ScienceDirect.

[9] Passmore, David L. 2011. Social Network Analysis Theory and Applications [online]. Tersedia http://code.pediapress.com/, tanggal akses: 27 November 2013.

[10] Umadevi. 2013. Journal of Global Research in Computer Science: Case study-Centrality Measure Analysis On Co-Authorship Network. Vol.4 no.1. Diperoleh dari: www.rroij.com.

[11] Schiffman, L.G dan Leslie Lazar Kanuk. 2010. Consumer Behavior tenth Edition. Pearson Education.

[12] Soheh \& Walujo. 2010. Efektifitas Tabloid Komunika Sebagai Media Diseminasi Informasi bagi pegawai Puslitbang Postel dan Puslitbang Uptel SKDI Badan Litbang SDM Depkominfo. Jurnal Komunikologi Volume 7 No.2. Jakarta.

[13] Sisrazeni. 2017. Hubungan Penggunaan Media Sosial dengan Interaksi Sosial Mahasiswa Jurusan Bimbingan Konseling Tahun 2016/2017 IAIN Batusangkar. 